\title{
Measurement properties of the construct of the code of ethics content: The South African experience
}

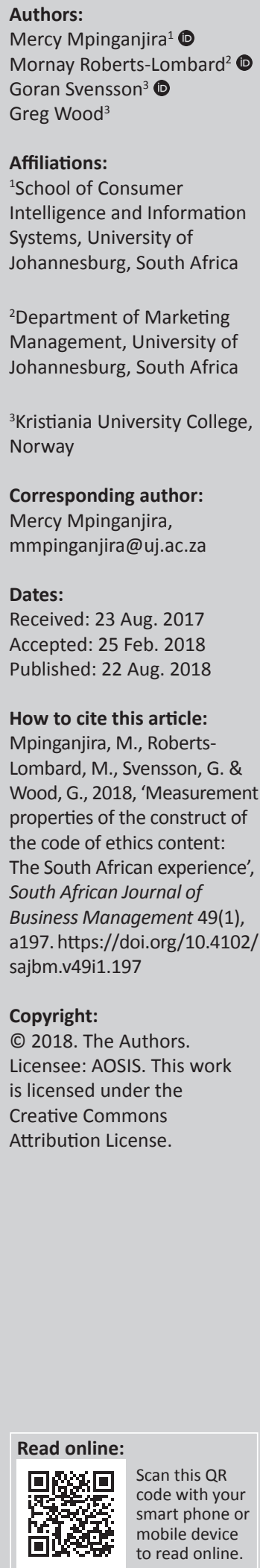

How to cite this article: Mpinganjira, M., RobertsLombard, M., Svensson, G. \& Wood, G., 2018, 'Measurement properties of the construct of the code of ethics content: The South African experience', South African Journal of Business Management 49(1), a197. https://doi.org/10.4102/ sajbm.v49i1.197

\section{Copyright:}

(C) 2018. The Authors. Licensee: AOSIS. This work is licensed under the Creative Commons Attribution License.

Background: Many organisations develop codes of ethics to help guide business conduct. However, not much is known about the contents of codes of ethics.

Objectives: This article aims at investigating the code of ethics content construct and its measurement properties using a sample of firms from South Africa.

Method: The study followed a quantitative research approach. The sampling frame consisted of the top 500 companies in South Africa. A structured questionnaire was administered using the telephone survey method. The respondents consisted of company secretaries and heads or managers responsible for ethics in the respective companies. At the end of the data collection period, a total of 222 usable responses were obtained.

Results: The findings show that South African top companies have comprehensive codes of ethics as evidenced by the high mean values obtained from all of the content items under investigation. The findings also support the notion that the code of ethics content construct is multidimensional. Seven different dimensions were confirmed in the analysis. The measurement model of the ethics content construct was found to be valid as evidenced by the goodness-of-fit measure and measures of validity.

Conclusion: The study shows that the code of ethics construct is multi-dimensional in nature. The framework provided in this study can also be used in developing, evaluating and strengthening existing codes where such need arises. This study contributes to theory on business ethics and presents the first tested measurement model of the code of ethics construct in South Africa.

\section{Introduction}

Jones et al. (2013:55) state that in an 'ever-increasing diverse working environment, in order to successfully liaise with colleagues, customers, and clients who are different from themselves, employees will continuously require relevant knowledge, skills, abilities, and attitudes'. They continue to argue that an organisation that supports diversity in the workplace needs to particularly initiate a stronger understanding for business ethics in the workplace so as to empower its employees to engage properly with a broader group of stakeholders. Singh et al. (2005:92) noted the contention of the Global Business Responsibility Resource Centre in 2001 relating to the growing importance of establishing a code of ethics in organisations in the developing world, notably in Africa, Asia and Latin America. The contention is that adopting universal standards, which transcend differences in laws and customs, would go a long way to establishing the ethical foundations that would lead to stronger business performance across these jurisdictions. This is because when an organisation wants to showcase to the world of business and its stakeholders that its commitment to an ethical organisational culture is strong, then the development of a code of ethics is paramount in attempting to achieve that goal (Axline 1990:87; Somers 2001:185). It is the code of ethics that showcases to the world the innermost soul of the organisation as it perceives itself to be and as it desires to be perceived by others.

As early as 1992, the Institute of Directors (IODs) in South Africa enacted the first of the four King Reports on corporate governance. Each report recommended that the practices in this area of corporate governance and the resultant interest in business ethics should evolve to the next level in order to inspire organisations to aspire to better practices in the marketplace. The publication of the first King Report in 1994 brought into sharp focus in South Africa the need for corporate governance amongst South African organisations. The report, amongst other things, suggested standards of conduct for boards and directors of companies. It highlighted the need for each company to become a responsible part of the society in which it operates. Sound organisational 
management and ethical leadership are two key requirements for an organisation to be perceived as successful by its stakeholders (Botha 2009:55).

Rossouw (1997) observed that in South Africa, the need for a prominent ethical culture in business had been expressed by politicians, business leaders and academics. He highlighted the fact that the former president Nelson Mandela stated at the opening of the South African Parliament on 17 February 1995 that:

We are conscious of the reality that corruption in many forms has deeply infected the fibre of our society. Precisely because we face the challenge of dealing with systematic corruption, we need a dispassionate and systematic approach to this question. (p. 1539)

Bisschoff and Fullerton (2011:15) contend that in alignment with the argument of the first King Report of 1994, the IODs suggested that there should be new guidelines for ethical practice in business enterprises in South Africa and that one of these guidelines should be for organisations to implement a code of ethics.

According to Van Tonder (2006:13), the King II Report that was published in 2002 succeeded in emphasising not only the need for but also the nature of corporate governance. It highlighted the need to pursue an inclusive stakeholder approach in corporate governance structured around a clear set of corporate ethics. The report emphasised clearly that companies cannot only focus on matters relating to economic efficiency without a greater focus being placed on ensuring positive societal impact. The King III Report which came into effect on 01 March 2010 was intended at motivating companies to embrace the concept of integrated reporting of financial information together with sustainability issues including social, economic and environmental impacts of companies (Makiwane \& Padia 2013:422). In so doing, stakeholders are able to assess a company's performances holistically in terms of its ability to create and sustain value for different stakeholders. Planting (2013:Online) highlights that a greater awareness of business ethics in South Africa has been driven by the King III Report, which includes the need to encourage companies to implement a code of ethics.

\section{Literature review}

One of the first artefacts that showcases that an organisation has an interest in being a better organisation is to establish a code of ethics or conduct (Wood \& Rimmer 2003:181). Langlois and Schlegelmilch (1990) define a corporate code of ethics as:
a statement setting down corporate principles, ethics, rules of conduct, codes of practice or company philosophy concerning responsibility to employees, shareholders, consumers, the environment, or any other aspects of society external to the company. (p. 522)

Some 25 years ago, Benson (1989:316) observed that codes of ethics were becoming more prominent because of the pressures of government regulation and that a benefit of this need to have a code of ethics was the fact that codes were leading to improvements in the way that business was conducted. Benson (1989:317) states that codes enabled management to connect with their stakeholders in a manner that was acceptable to their civilised societies in order to maintain harmonious relationships within that society. This principle of living by universally accepted standards in order for a harmonious society to exist is not a new idea, as was cited by Chonko, Wotruba and Loe (2003:249) who wrote of the Code of Hammurabi in ancient Babylon that was a moral code to be followed by all for the betterment of all.

Codes of conduct of a high standard can be beneficial in enhancing the success of an organisation (Höhn 2012:381). A well-developed code of conduct can assist an organisation with aspects in their operations such as preventing legal suits and fostering customer as well as employee loyalty. Other potential benefits include building strong relations with business partners including suppliers and strengthening trust with other stakeholders including local communities, regulators and non-governmental organisations (NGOs). Ruiz et al. (2014:738) pointed out that a code of ethics is a critical element of an ethics programme as it helps predict whether employees would be ethical in their behaviour on behalf of their organisation. Bodolica and Spraggon (2015:468) suggest that a code not only sets the tone for behavioural expectations within the organisation, but also gives an indication of the ethical values that the company wishes to instil within all employees of the organisation. A code of ethics is thus critical in ensuring employee adherence to the ethical values of the organisation.

Kaptein and Schwartz (2008) come to the conclusion that:

a business code is a distinct and formal document containing a set of prescriptions developed by and for a company to guide present and future behaviour on multiple issues of at least its managers and employees towards one another, the company, external stakeholders and/or society in general. (p. 113)

Examining the content of a business code, or code of ethics, gives insights into the focus of organisations and the expected behaviour of employees at all levels of the organisation that these organisations see as being of benefit to the organisation. Preuss (2010) believes that:

codes of conduct are another example of the active role that companies play in shaping the debate as to what the social and environmental responsibilities of business should and should not be. (p. 484)

This notion is the intent of the King Reports in South Africa that were brought down in order to shape and to guide and direct the debate into the ethical responsibilities of businesses. As former president Mandela had made it clear in his 1995 speech, more of the same was no longer acceptable.

Erwin (2011:536) comments that 'codes of conduct have become a nearly ubiquitous feature' across North America, 
Europe and in the majority of companies worldwide. In the last 30 years, a number of codes of ethics studies have been conducted in the developed world. Examples of such studies include, but are not limited to, Berenbeim (2000), Mathews (1987) and Chonko et al. (2003) in the USA; Langlois and Schlegelmilch (1990), Preuss (2010) and Whyatt, Wood and Callaghan (2012) in the UK; Winkler (2011) in Germany; O'Dwyer and Madden (2006) in Ireland; LeFebvre and Singh (1992), Schwartz (2002) and Singh et al. $(2005 ; 2011)$ in Canada; Aydinlik et al. (2008) and Svensson, Wood and Callaghan (2004; 2006) in Sweden; and Callaghan and Wood (2014), Callaghan, Wood and Svensson (2008) and Farrell and Cobbin (1996) in Australia. Code studies have also been conducted on company operations spanning different countries. Examples of such studies include Béthoux, Didry and Mias (2007), Carasco and Singh (2003), Kaptein (2004), Singh et al. (2005), Stohl, Stohl and Popova (2009), Svensson et al. (2009; 2011), Wood et al. (2004) and Callaghan et al. (2012).

Preuss, Barkemeyer and Glavas (2016:5) comment that, '... studies into the adoption of codes in developing countries are still rare'. In South Africa, there have been limited studies in the area of business ethics in South African companies (Abratt, Bendixen \& Drop 1999; Buys \& van Schalkwyk 2015; Erasmus \& Wordsworth 2006; Lloyd, Mey \& Ramalingum 2014), with none of them that can be found in the extant literature specifically focused upon codes of ethics content in the top companies.

This study builds upon the works of Lefebvre and Singh (1992), Mathews (1987), Singh et al. (2005; 2011), Svensson et al. (2009) and Wood (2000) in which the contents of codes of ethics across the USA, Australia, Canada and Sweden were analysed to see what they revealed about the organisations that had one. The areas of content that were examined within the codes fell within the following areas:

- a-e Conduct on behalf of the company

- $\mathrm{f}-\mathrm{j}$ Conduct against the company

- $\mathrm{k}-\mathrm{o}$ Laws and conventions cited

- $\mathrm{p}-\mathrm{r}$ Reference to governmental agencies or commissions

- $\quad \mathrm{s}-\mathrm{v}$ Compliance and enforcement procedures

- w-y Penalties for illegal behaviour

- z General information about or from the company.

This article tests the construct for codes of ethics for the first time in a South African context.

\section{Method}

The target population for the study was the top 500 companies in South Africa based on financial performance. The companies were identified using a published list produced by TopCo which lists the top 500 companies in the country every year. All of the top 500 companies on the list were targeted for data collection. The data collection process involved contacting each company in order to get the contact details of the manager under whom development and enforcement of ethics primarily falls. Upon identification, the respondents were contacted and invited to participate in the study. The managers identified were mainly from the corporate governance and legal departments and included company secretaries and heads of ethics areas or ethics managers.

A structured questionnaire using the computer-assisted telephone survey method was then administered. At the end of the data collection period, 222 usable questionnaires were collected. This number represented an effective response rate of $44.4 \%$ of which all had codes. This figure is much lower than that of Preuss et al. (2016:14) who report an 80\% uptake of codes in corporate South Africa in their extensive groundbreaking survey of the corporate codes of 568 companies across 20 developing economies. This difference is explained in the sample sizes and target groups of the two South African studies, where their sample size was 15 multinational companies as compared with the top 500 corporate companies that were surveyed in this study.

The majority of the responding companies (17\%) are from the manufacturing sector, $11.2 \%$ were from personal and other services, $9.9 \%$ were in retail trade, $7 \%$ were in transport and storage, while $6.3 \%$ were in communication services. Ninety-six per cent of the respondents had a total of 201 or more employees in their service.

\section{Measures and scale items}

Of interest in the study were seven constructs relating to the contents of organisational codes of conduct as previously proposed by Wood, Svensson, Singh and Callaghan in their previous works in this area. The constructs included the relationship of code contents to (1) conduct on behalf of the company, (2) conduct against the company, (3) laws or conventions citation, (4) reference to government agencies or commissions, (5) compliance or enforcement procedures, (6) penalties and (7) general information about and from the company. Each contrast was measured using a total of three items. The constructs and items used to assess the content of the codes were sourced from the literature including studies by Singh et al. (2005:100-102; 2011:108-116). A five-point semantic differential scale ranging from $1=$ 'not at all' to 5 = 'comprehensively' was used to measure the items. The respondents were specifically asked to indicate from their perspective the extent to which they regarded their organisations' codes to contain the different aspects under investigation. Details of the items statements and the associated constructs are provided in Table 1.

\section{Data analysis}

The data were analysed using version 21 of SPSS/AMOS software. The main techniques used in the analysis included descriptive analysis, exploratory and confirmatory factor analysis. Descriptive analysis was conducted in order to check the extent to which the different organisational codes actually contained the different aspects under investigation. Results of the descriptive analysis are provided in Table 1. Exploratory analysis was conducted in order to assess the 
TABLE 1: Scale items and univariate descriptives.

\begin{tabular}{|c|c|c|c|}
\hline Code content & Item & Mean & Std. Dev. \\
\hline \multirow{3}{*}{$\begin{array}{l}\text { Conduct on behalf } \\
\text { (of the company) }\end{array}$} & (a) It (i.e. YOUR company code) describes conduct on behalf of the company. & 4.73 & 0.509 \\
\hline & (b) It addresses the company's relations with different internal stakeholders. & 4.33 & 0.729 \\
\hline & (c) It mentions our company's relations with different external stakeholders. & 4.26 & 0.756 \\
\hline \multirow{3}{*}{$\begin{array}{l}\text { Conduct against } \\
\text { (the company) }\end{array}$} & (d) It addresses conflict of interest. & 4.45 & 0.722 \\
\hline & (e) It addresses the acceptance of gifts and/or bribes. & 4.39 & 0.739 \\
\hline & (f) It comments on staff responsibilities to the company. & 4.45 & 0.715 \\
\hline & (h) It makes reference to conventions about human rights. & 4.32 & 0.745 \\
\hline & (i) It addresses conventions about work health and/or safety. & 4.33 & 0.764 \\
\hline \multirow{3}{*}{$\begin{array}{l}\text { Reference (to governmental } \\
\text { agencies or commissions) }\end{array}$} & (j) It makes reference to governmental agencies. & 4.19 & 0.829 \\
\hline & (k) It mentions organisations such as UN or similar entities. & 4.02 & 0.998 \\
\hline & (I) It refers to entities such as OECD, EU or similar bilateral agreements. & 4.05 & 0.987 \\
\hline \multirow{2}{*}{$\begin{array}{l}\text { Compliance or enforcement } \\
\text { (procedures) }\end{array}$} & (m) It considers procedures of law enforcement. & 4.39 & 0.733 \\
\hline & (n) It considers the use of external auditors. & 4.33 & 0.746 \\
\hline \multirow{3}{*}{$\begin{array}{l}\text { Penalties } \\
\text { (for illegal behaviour) }\end{array}$} & (p) It includes stipulations for illegal behaviour. & 4.48 & 0.684 \\
\hline & (q) It has internal penalties for breaches of the code (e.g. reprimand and/or fine). & 4.41 & 0.710 \\
\hline & (r) It contains external penalties for breaches of the code (e.g. legal prosecution). & 4.41 & 0.704 \\
\hline \multirow{3}{*}{$\begin{array}{l}\text { General information } \\
\text { (about or from company) }\end{array}$} & (s) It includes general information about our company. & 4.49 & 0.678 \\
\hline & (t) It has a letter from the top management of our company to staff. & 4.41 & 0.692 \\
\hline & (u) It contains introductory words from our corporate leadership. & 4.50 & 0.636 \\
\hline
\end{tabular}

OECD, Organisation for Economic Co-operation and Development; EU, European Union; UN, United Nations; Std. dev., standard deviation.

underlying dimensions in the data and items associated with them. The principal component was used to extract the factors. The initial factor solution was rotated using the varimax rotation method.

According to Hair et al. (2010:99), factor rotation helps one achieve a simpler and more theoretically meaningful factor pattern. The results of the exploratory factor analysis are presented in Table 2. The exploratory factor analysis was followed by confirmatory factor analysis which was performed in order to assess the goodness of fit of the measurement model of the construct for ethics code content. The reliability and validity of the construct were also assessed.

\section{Empirical findings}

The results in Table 1 show that all of the items used in the study had mean values of greater than four. This shows satisfactory consistency across items. The item with the lowest mean was the one noting that the code makes mention of organisations such as the United Nations or similar entities. The mean for this item was 4.02 . The item with the highest mean was the one in which the company code described conduct on behalf of the company. The mean for this item was 4.73 . Keeping in mind that a five-point scale was used in this study, the findings do not only show high levels of consistency, but also show that companies in the study regard the contents under investigation as important enough to be worth including in their written codes ethics.

The results of the exploratory factor analysis conducted, presented in Table 2, show that while the number of dimensions remained at 7 , not all of the 21 items loaded on the seven dimensions. Four dimensions retained their three original items, while three lost an item each that did not load on any other dimension. The dimensions that retained their three original items included those relating to general information about or from the company, reference to government agencies or commissions, conduct against the company and the one on citation of laws or conventions. The three dimensions that had two items each loading on them included those with content relating to conduct on behalf of the company, penalties for illegal behaviour and compliance or enforcement procedures.

It is to be noted that Bartlett's test of sphericity and the Kaiser-Meyer-Olkin (KMO) measure of sampling adequacy were used in the study to assess the suitability of the data for factor analysis. The results of the test of overall adequacy, presented in Table 3, show that the data were suitable for factor analysis as per Hair et al. (2010:104). The KMO was found to be above the recommended minimum value of 0.5 , while Bartlett's test of sphericity was found to be significant.

After the exploratory factor analysis, confirmatory factor analysis was conducted using the 18 items that loaded on the seven dimensions associated with the ethics code content. Figure 1 shows the measurement model.

The results of the confirmatory factor analysis generated satisfactory findings. The goodness-of-fit measures, as shown in Table 4, were acceptable as per Hair et al. (2010:672) and Hooper, Coughlan and Mullen (2008:53-55). Specifically, the results in Table 4 show that the chi-square value (CMIN) was 214.267, while the degrees of freedom was 114 resulting in normed chi-square (CMIN/df) value of 1.880. According to Hair et al. (2010), $\chi^{2}$ :df ratios of 3:1 or less are associated with better fitting models. Normed Fit Index (NFI), Tucker-Lewis Index (TLI), Incremental Fit Index (IFI) and Comparative Fit Index (CFI) values approaching 1 are also considered indicative of good model fit. Some authors including Hooper et al. (2008:53-55) recommend values of 0.9 and more. 
TABLE 2: Exploratory factor analysis - Code of ethics content.

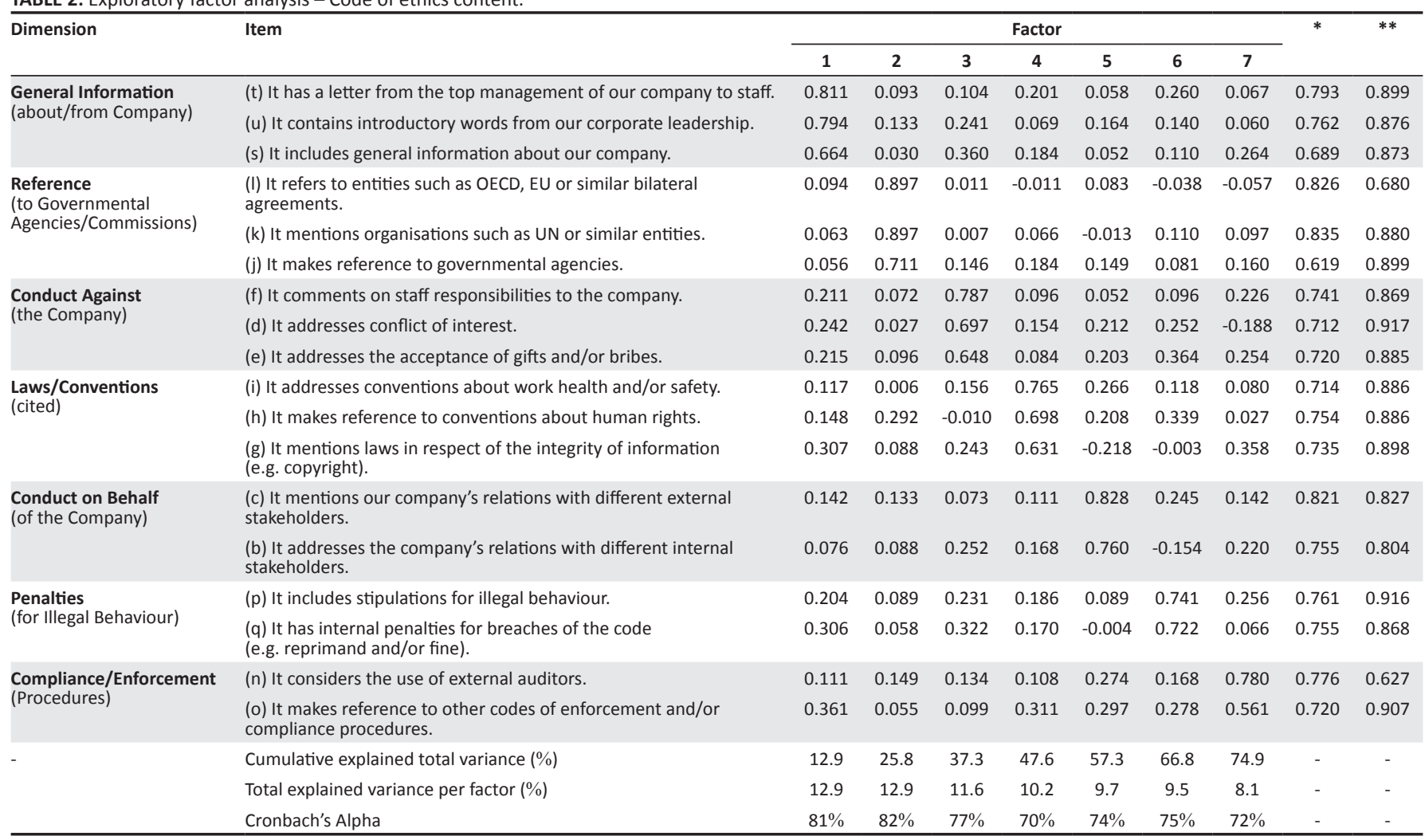

${ }^{*}$ Communality per item; ${ }^{* *}$ measures of sampling adequacy (MSA per item).

OECD, Organisation for Economic Co-operation and Development; EU, European Union; UN, United Nations.

TABLE 3: Kaiser-Meyer-Olkin and Bartlett's test.

\begin{tabular}{lc}
\hline Bartlett's test of sphericity & Total \\
\hline Approx. chi-square & 1798.18 \\
df & 210 \\
Sig. & 0.000 \\
Kaiser-Meyer-Olkin measure of sampling adequacy & 0.865 \\
\hline
\end{tabular}

$\mathrm{df}$, degrees of freedom; Sig., level of significance.

The findings in this study show that findings on the IFI, TLI as well as the CFI all met this condition. Although the NFI was below the 0.9 mark, the value of 0.880 was not considered too low to be of much concern more so bearing in mind that when presented to one decimal place it will be 0.9 . With regard to the root mean square error of approximation (RMSEA), Hooper et al. (2008:54) note that the general consensus shows that values of 0.07 or lower indicate good model fit.

\section{Construct reliability and validity}

Composite trait reliability was used to assess the reliability of the different dimensions of the model. The results, as presented in Table 5, show that all dimensions had values of greater than the recommended 0.7 as per Hair et al. (2010:710). The values specifically ranged from 0.78 to 0.86 . The variance extracted for all of the variables except one (laws or conventions) was over $50 \%$. Despite this, the factor loadings for all items associated with laws or conventions were, however, all above 0.5 . The results thus provide support for acceptable convergent validity. Furthermore, we compared the variance extracted to the squared inter-construct correlations to examine whether the research model measures

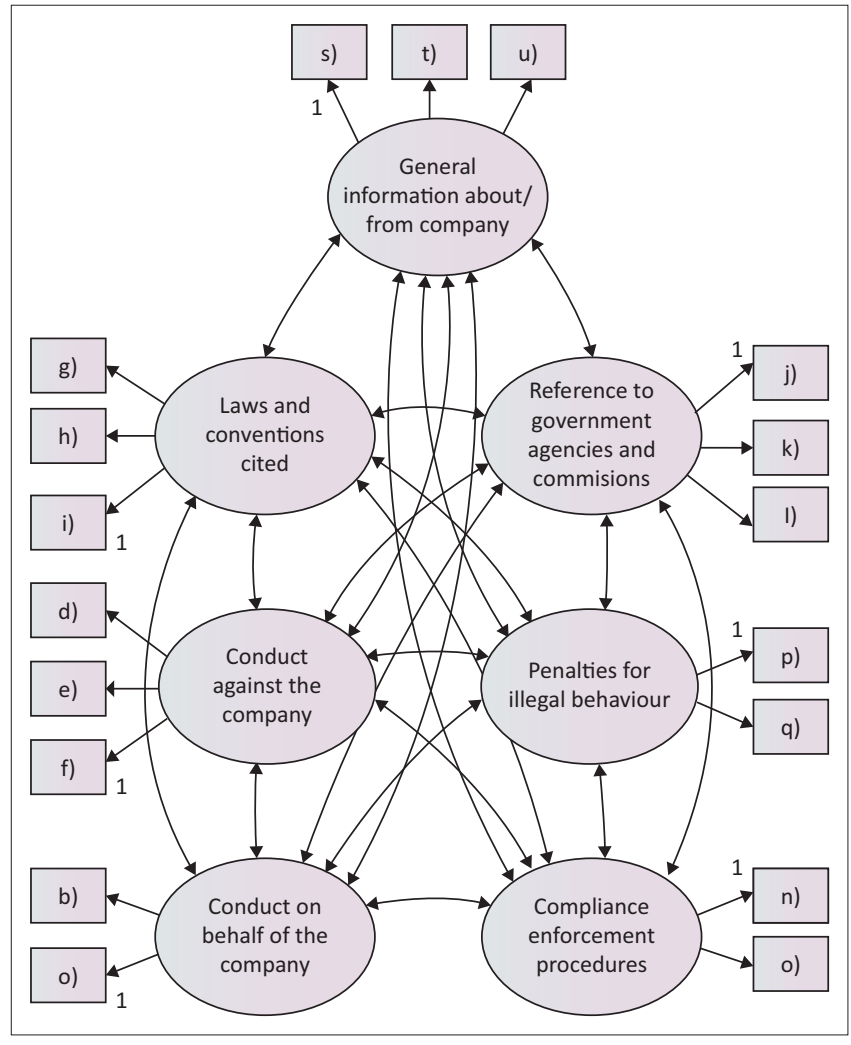

FIGURE 1: Code of ethics measurement model.

were separated constructs (Hair et al. 2010). The variance extracted was larger for all constructs in relation to the corresponding squared inter-construct correlations except two 
TABLE 4: Measurement model - Goodness-of-fit measures.

\begin{tabular}{lcccccccc}
\hline CMIN & DF & $\boldsymbol{P}$ & CMIN/DF & NFI & IFI & TLI & CFI & RMSEA \\
\hline 214.267 & 114 & 0.000 & 1.880 & 0.88 & 0.94 & 0.92 & 0.94 & 0.063
\end{tabular}

CMIN, chi-square value; $D F$, degrees of freedom; $P$, calculated probability; CMIN/DF, normed chi-square; NFI, normed fit index; IFI, Bollen's incremental fit index; CFI, comparative fit chi-square; $\mathrm{NFl}$, normed fit index; IFI, Bollen's

TABLE 5: Squared inter-construct correlations and summary statistics.

\begin{tabular}{lccccccc}
\hline Variable & (1) & (2) & (3) & (4) & (5) & (6) & (7) \\
\hline (1) Conduct on behalf & 1.00 & - & - & - & - & - & - \\
(2) Conduct against & 0.29 & 1.00 & - & - & - & - & - \\
(3) Laws or conventions & 0.28 & 0.34 & 1.00 & - & - & - & - \\
(4) Reference government & 0.07 & 0.05 & 0.14 & 1.00 & - & - & - \\
(5) Compliance or enforcement & 0.42 & 0.42 & 0.56 & 0.07 & 1.00 & - & - \\
(6) Penalties & 0.18 & 0.62 & 0.47 & 0.06 & 0.43 & 1.00 & - \\
(7) General information & 0.19 & 0.54 & 0.44 & 0.06 & 0.48 & 0.56 & 1.00 \\
Variance extracted & $56 \%$ & $55 \%$ & $48 \%$ & $62 \%$ & $58 \%$ & $60 \%$ & $58 \%$ \\
Composite trait reliability & 0.78 & 0.83 & 0.79 & 0.86 & 0.78 & 0.79 & 0.85 \\
\hline
\end{tabular}

(conduct against or penalties -0.62 and laws or conventions or compliance or enforcement - 0.56), as shown in Table 5. From the findings, we can conclude that the model provides reasonable support for acceptable discriminant validity.

In summary, the testing of the code content construct in the South African context through exploratory and confirmatory factor analyses accomplished the requirements for convergent, discriminant and nomological validity as well as construct reliability. It can therefore be concluded that the measurement properties of the code content construct can be applied in South African business-supplier relationships.

\section{Discussion and implications}

The empirical findings offer several implications to both research and practice. From a theoretical perspective, the findings offer knowledge on the measurement properties of the construct of code of ethics, as shown in Figure 1. Most previous research internationally on codes of ethics has paid little attention to issues of the measurement properties of the construct. The findings in this study point to the importance of seven dimensions making up the code of ethics construct. These dimensions include general information about or from the company, reference to government agencies or commissions, conduct against the company, law or conventions cited, conduct on behalf of the company, penalties for illegal behaviour and compliance or enforcement procedures. The findings in this study lend support to the existing literature including studies by Singh et al. (2005:102$103 ; 2011: 107)$ who view codes of ethics as made up of various dimensions. The findings also show the interrelationships that exist between the different dimensions uncovered.

From a practical perspective, the findings in the study can help managers interested in developing, evaluating or strengthening their organisational codes of ethics to understand the different aspects upon which they need to focus. The dimension entitled 'general information about or from the company' points to the need for managers to realise the fact that one of the main functions for having a code is to protect the company from behaviours that can emanate from both inside and outside of the organisation (Singh et al. 2005:105-106). It is thus important that the codes describe conduct that is in relation to people's roles on behalf of the company and identify the different internal and external stakeholders of the organisation. This dimension is closely associated with the dimensions of conduct on behalf of the company and one on conduct against the company.

These dimensions speak about the need to be specific on activities relating to internal and external stakeholders including specific acts that the organisation clearly considers to be against its best interests. The code of conduct, for example needs to provide guidance on what one needs to do in cases where conflict of interest may arise or in cases where one is offered gifts, or worse still offered bribes or even that one asks for bribes. By ensuring that an organisation's code covers internal and external stakeholders and is as explicit as possible in terms of specific conduct, management can help to promote a sense of responsibility amongst employees towards living the ethos of the codes and the codes being used to facilitate ethical decision-making. This is particularly so as the code will speak directly to the roles in the organisations about staff and those activities associated with those roles.

Having points of reference including making reference to government agencies or commissions as well as laws and conventions, can help enhance individuals' appreciation of their organisations' codes. This is because in so doing, the organisation is able to show that its codes are not a product of arbitrary thinking, but are in line with what society in general expects. It can also help demonstrate an organisation's sense of moral obligation not only for one's self-good, but also for the good of society within the codes that can only but be helpful. For example, the codes can make reference to acts that speak about health and safety in the workplace and or the integrity of information or conventions about human rights. By citing specific laws, management can help bring about more of a sense of obligation and a need for compliance because the violation of laws invariably comes with penalties.

A code of ethics cannot be effective in promoting ethical behaviour if it fails to address the issues of compliance and enforcement procedures as well as penalties for illegal behaviour. At the basic level, compliance speaks to the obligations of those acting on behalf of the company to act in a way that is in line with a set of ethical standards. Davis (2001:160) describes a code of ethics as a form of contractual agreement that obligates a member of an organisation to act in accordance with set standards. Compliance procedures, amongst other things, thus need to speak to the need to make sure that people are aware of the conduct expected of them. It would be unfair to expect individuals to comply with ideas of which they are not made aware. Compliance also needs to address the issue of who will be responsible for monitoring compliance and to have in place procedures for handling non-compliance. Penalties for illegal behaviour need to be clearly spelt out and be in line with the seriousness 
of the breach of conduct. The ability of managers to ensure that their codes of ethics address the different dimensions identified in this area can help enhance the effectiveness of codes in promoting and addressing ethical concerns and also in providing guidance on the company's embedded views and values about doing business in an ethical manner.

\section{Conclusion and suggestions for future research}

This study investigated the construct of code of a ethics content with a special focus on its measurement properties. From the findings, it can be concluded that the construct is multidimensional in nature. Seven specific dimensions were specifically confirmed using factor analysis. The findings show support for the nomological, convergent and discriminant validity of construct. In so doing, this study introduces an empirical foundation beyond Singh et al. (2005; 2011) of a code content construct that consists of specific items to each dimension. This construct may be used by both researchers and practitioners to assess the content of codes across contexts and over time.

Furthermore, the empirical findings of this study provide valuable opportunities for further research into how the dimensions of the content of codes of ethics are intertwined and interconnected as indicated by the empirical findings based upon corporate perceptions. In summary, the current study makes an essential and relevant contribution to previous studies and existing theory on developing measurement properties of a code (of ethics) content construct. While this is so, the study is not without limitations which need to be borne in mind when interpreting the findings.

One of the limitations of the study is that the findings are based on a sample of only large firms in South Africa. This limits the extent to which the findings can be generalised to small- and medium-sized firms. Future research can take this situation into consideration by testing the construct on a sample of small- and medium-sized firms. Another limitation is that the sample consists of firms drawn from different industries. This investigation did not look at differences at industry level in terms of the content of codes of ethics of companies. Future research can also look at this issue in order to uncover similarities or differences at the industry level.

\section{Acknowledgements Competing interests}

The authors declare that they have no financial or personal relationships which may have inappropriately influenced them in writing this article.

\section{Authors' contributions}

All the authors contributed to the planning of the research and the writing of the article.

\section{References}

Abratt, R., Bendixen, M. \& Drop, K., 1999, 'Ethical perceptions of South African retailers: Management and sales personnel', International Journal of Retail \& Distribution Management 27(2), 91-105. https://doi.org/10.1108/09590559910258616

Axline, L.L., 1990, 'The bottom line on ethics: A fresh perspective on a worthwhile subject', Journal of Accountancy 170(6), 87.

Aydinlik, A., Donmez, D., Svensson, G., Wood, G. \& Callaghan, M., 2008, ‘Communicating the ethos of codes of ethics within the organization: A comparison of the largest private sector organizations in Sweden and Turkey', Journal of Management private sector organizations in Sweden and Turkey', Journal of Manage
Development 27(7), 778-790. https://doi.org/10.1108/02621710810883652

Benson, G.C., 1989, 'Codes of ethics', Journal of Business Ethics 8(5), 305-319. https:// doi.org/10.1007/BF00381721

Berenbeim, R., 2000, 'Global ethics', Executive Excellence 17(5), 7.

Béthoux, É., Didry, C. \& Mias, A., 2007, 'What codes of conduct tell us: Corporate social responsibility and the nature of the multinational corporation', Corporate Governance: An International Review 15(1), 77-90. https://doi.org/10.1111/ j.1467-8683.2007.00544.x

Bisschoff, C. \& Fullerton, S., 2011, 'Managerial business ethics in South Africa: An exploratory comparison - 1987 and 2009', African Journal of Business Ethics 5(1) $14-25$.

Bodolica, V. \& Spraggon, M., 2015, 'An examination into the disclosure, structure, and contents of ethical codes in publicly listed acquiring firms', Journal of Business Ethics 126(3), 459-472. https://doi.org/10.1007/s10551-013-1966-x

Botha, H., 2009, 'Corporate governance, leadership and ethics: Interrelated trio', Management Today 25(2), 55-57.

Buys, F. \& van Schalkwyk, T., 2015, 'The relevance of ethical conduct in creating a competitive advantage for entry-level emerging contractors', Acta Structilia 22(2), 81-109.

Callaghan, M. \& Wood, G., 2014, 'The engagement with business ethics: An Australian journey 1995-2010', European Business Review 26(4), 286-304. https://doi. org/10.1108/EBR-11-2013-0138

Callaghan, M., Wood, G., Payan, J.M., Singh, J. \& Svensson, G., 2012, 'Code of ethics quality: An international comparison of corporate staff support and regulation in Australia, Canada and the United States', Business Ethics: A European Review 21(1), 15-30. https://doi.org/10.1111/j.1467-8608.2011.01637.x

Callaghan, M., Wood, G. \& Svensson, G., 2008, 'A longitudinal study of the commitment to business ethics of corporate Australia', International Journal of Entrepreneurship and Small Business 6(1), 173-184. https://doi.org/10.1504/IJESB.2008.017397

Carasco, E.F. \& Singh, J.B., 2003, 'The content and focus of the codes of ethics of the world's largest transnational corporations', Business and Society Review 108(1) 71-94. https://doi.org/10.1111/1467-8594.00007

Chonko, L.B., Wotruba, T.R. \& Loe, T.W., 2003, 'Ethics code familiarity and usefulness: Views on idealist and relativist managers under varying conditions of turbulence', Journal of Business Ethics 42(3), 237-252. https://doi.org/10.1023/A:1022261006692

Davis, M. 2001, 'The place of a code of ethics in the practice of a profession', Business Ethics: Critical Perspectives on Business and Management 2(2), 243-257.

Erasmus, B.J. \& Wordsworth, R., 2006, 'The views of HR practitioners on ethical issues within organisations: A South African perspective', South African Journal of Economic and Management Sciences 9(4), 413-428.

Erwin, P.M., 2011, 'Corporate codes of conduct: The effects of code content and quality on ethical Performance', Journal of Business Ethics 99(4), 535-548. https:// doi.org/10.1007/s10551-010-0667-y

Farrell, B.J. \& Cobbin, D.M., 1996, 'A content analysis of codes of ethics in Australian enterprises', Journal of Managerial Psychology 11(1), 37-55. https://doi.org/ 10.1108/0268394961010938

Hair, J., Black, W., Babin, B. \& Anderson, R., 2010, Multivariate data analysis: A globa perspective, Pearson Education, Upper Saddle River, NJ.

Höhn, S., 2012, 'Accounts and accountability: Global norms and codes of conduct in Namibian advocacy NGOs', Commonwealth \& Comparative Politics 50(3), 367-389. https://doi.org/10.1080/14662043.2012.692927

Hooper, D., Coughlan, J. \& Mullen, M.R., 2008, 'Structural equation modelling: Guidelines for determining model fit', The Electronic Journal of Business Research Methods 6(1), 53-60.

Jones, K.P., King, E.B., Nelson, J., Geller, D.S. \& Bowes-Sperry, L., 2013, 'Beyond the business case: An ethical perspective of diversity training', Human Resource Management 52(1), 55-74. https://doi.org/10.1002/hrm.21517

Kaptein, M., 2004, 'Business codes of multinational firms: What do they say?', Journal of Business Ethics 50(1), 13-31. https://doi.org/10.1023/B:BUSI.0000021051.53460.da

Kaptein, M. \& Schwartz, M.S., 2008, 'The effectiveness of business codes: A critical examination of existing studies and the development of an integrated research model', Journal of Business Ethics 77(2), 111-127. https://doi.org/10.1007/ s10551-006-9305-0

Langlois, C.C. \& Schlegelmilch, B.B., 1990, 'Do corporate codes of ethics reflect national character? Evidence from Europe and the United States', Journal of International Business Studies, Fourth Quarter 21(4), 519-539.

Lefebvre, M. \& Singh, J.B., 1992, 'The content and focus of Canadian corporate codes of ethics', Journal of Business Ethics 11(10), 799-808. https://doi.org/10.1007/ BF00872312

Lloyd, H. R., Mey, M.R. \& Ramalingum, K., 2014, 'Ethical business practices in the Eastern Cape automotive industry', South African Journal of Economic and Management Sciences 17(5), 569-583. https://doi.org/10.4102/sajems.v17i5.638 
Makiwane, T.S. \& Padia, N., 2013, 'Evaluation of corporate integrated reporting in South Africa post King III release South Africa-an exploratory enquiry', Journal of Economic and Financial Sciences 6(2), 421-438.

Mathews, M.C., 1987, 'Codes of ethics: Organizational behavior and misbehavior' Research in Corporate Social Performance and Policy 9, 107-130.

O'Dwyer, B. \& Madden, G., 2006, 'Ethical codes of conduct in Irish companies: A survey of code content and enforcement procedures', Journal of Business Ethics 63(3), 217-236. https://doi.org/10.1007/s10551-005-3967-x

Planting, S., 2013, SA's bi-polar relationship with ethics, viewed 12 April 2016, from http://www.moneyweb.co.za/archive/sas-bipolar-relationship-with-ethics/

Preuss, L., 2010, 'Codes of conduct in organisational context: From cascade to latticework of codes', Journal of Business Ethics 94(4), 471-487. https://doi.org/10.1007/ s10551-009-0277-8

Preuss, L., Barkemeyer, R. \& Glavas, A., 2016, 'Corporate social responsibility in developing country multinationals: Identifying company and country-level developing country multinationals: Identifying company and country-level
influences', Business Ethics Quarterly 26(3), 347-378. https://doi.org/10.1017/ influences', Busi

Rossouw, G. J., 1997, 'Business Ethics in South Africa', Journal of Business Ethics 16(14) 1539-1547. https://doi.org/10.1023/A:1005858930223

Ruiz, P., Martinez, R., Rodrigo, J. \& Diaz, C., 2014, 'Level of coherence among ethics program components and its impact on ethical intent', Journal of Business Ethics 120(1), 95-108.

Schwartz, M.S., 2002, 'A code of ethics for corporate code of ethics', Journal of Business Ethics 41(1/2), 27-43. https://doi.org/10.1023/A:1021393904930

Singh, J., Carasco, E., Svensson, G., Wood, G. \& Callaghan, M., 2005, 'A comparative study of the contents of corporate codes of ethics in Australia, Canada and Sweden', Journal of World Business 40(1), 91-109. https://doi.org/10.1016/j. jwb.2004.10.007

Singh, J., Svensson, G., Wood, G. \& Callaghan, M., 2011, 'A longitudinal and crosscultural study of the contents of codes of ethics of Australian, Canadian and Swedish corporations', Business Ethics: A European Review 20(1), 103-119. https://doi.org/10.1111/j.1467-8608.2010.01612.x

Somers, M.J., 2001, 'Ethical codes of conduct and organizational context: A study of the relationship between codes of conduct, employee behavior and organizational values', Journal of Business Ethics 30(2), 185-195. https://doi.org/10.1023/A: 1006457810654
Stohl, C., Stohl, M. \& Popova, L., 2009, 'A new generation of corporate codes of ethic', Journal of Business Ethics 90(4), 607-622. https://doi.org/10.1007/s10551-009Journal

Svensson, G., Wood, G. \& Callaghan, M., 2004, 'A comparison between corporate and public sector business ethics in Sweden', Business Ethics: A European Review 13(2-3), 166-184. https://doi.org/10.1111/j.1467-8608.2004.00361.x

Svensson, G., Wood, G. \& Callaghan, M., 2006, 'Codes of ethics in corporate Sweden', Corporate Governance: The International Journal of Business in Society 6(5), 547-566. https://doi.org/10.1108/14720700610706054

Svensson, G., Wood, G., Singh, J. \& Callaghan, M., 2009, 'Implementation, communication and benefits of corporate codes of ethics: An international and longitudinal approach for Australia, Canada and Sweden', Business Ethics: A European Review 18(4), 389-407. https://doi.org/10.1111/j.1467-8608.2009.01571.x

Svensson, G, Wood, G, Singh, J, Payan, J.M. \& Callaghan, M., 2011, 'The embeddedness of codes of ethics in organizations in Australia, Canada and the United States' Business Ethics: A European Review 20(4), 405-417. https://doi.org/10.1111/ j.1467-8608.2011.01623.x

Van Tonder, C.L., 2006, 'Towards a minimum conceptualisation of ethnic organisational change: The platform provided by the King II Report', SA Journal of Human Resource Management 4(3), 12-21. https://doi.org/10.4102/sajhrm.v4i3.97

Whyatt, G., Wood, G. \& Callaghan, M., 2012, 'Commitment to business ethics in UK organizations', European Business Review 24(4), 331-350. https://doi.org/10.1108/ 09555341211242141

Winkler, I., 2011, 'The representation of social actors in corporate codes of ethics How code language positions internal actors', Journal of Business Ethics 101(4), 653-665. https://doi.org/10.1007/s10551-011-0762-8.

Wood, G., 2000, 'A cross cultural comparison of the contents of codes of ethics: USA, Canada and Australia', Journal of Business Ethics 25(4), 287-298. https://doi. org/10.1023/A:1006034209956

Wood, G. \& Rimmer, M., 2003, 'Codes of ethics: What are they really and what should they be?' International Journal of Value Based Management 16(2), 181-195. https://doi.org/10.1023/A:1024089509424

Wood, G., Svensson, G., Singh, J., Carasco, E. \& Callaghan, M., 2004, 'Implementing the ethos of corporate codes of ethics: Australia, Canada, and Sweden', Business Ethics: A European Review 13(4), 389-403. https://doi.org/10.1111/j.1467-8608. 2004.00378 